\title{
Spontaneous closure of degenerative lamellar macular hole with epiretinal membrane proliferation
}

Rony C. Preti ${ }^{*}{ }^{*}$, Leandro C. Zacharias ${ }^{1}$, Leonardo P. Cunha ${ }^{1,2}$, Mario L. R. Monteiro ${ }^{1}$ and David Sarraf 3,4

\begin{abstract}
Background: To describe the spontaneous closure of a degenerative lamellar macular hole with epiretinal proliferation (LHEP) as documented with tracked spectral domain optical coherence tomography (SD-OCT).

Case presentation: A 54-years-old diabetic female patient presented with progressive vision loss in the left eye. SD-OCT illustrated LHEP associated with cystic fluid in the outer nuclear layer. Sequentially tracked SD-OCT showed progressive closure of the degenerative lamellar macular hole and resolution of the CME over almost 4 years, in the absence of any surgical intervention.

Discussion/conclusion: LHEP may represent a specialized form of degenerative epiretinal membrane associated with Muller cell activation. Spontaneous degenerative LMH closure may rarely occur with these lesion types, in the absence of surgical intervention, possibly due to Muller cell proliferation preceded by PVD.

Keywords: Lamellar macular hole, Epiretinal proliferation, Epiretinal membrane, Lamellar hole-associated epiretinal proliferation, Spectral domain optical coherence tomography
\end{abstract}

\section{Introduction}

Lamellar macular hole (LMH) with epiretinal proliferation or LHEP is a unique form of degeneration associated with secondary Muller Cell proliferation [1]. These ERM variants are not as amenable to a peeling procedure because of the friable Muller Cell component, the stable natural history, and the unpredictable surgical outcomes, and therefore the surgical option is often deferred [2]. Goveto et al. recently classified LMH into two subtypes: Tractional ERMs associated with outer macular schisis and a degenerative subtype consistent with LHEP [3].

In this report, an interesting case of LHEP is presented in which the lamellar macular hole spontaneously closed without surgical intervention. We present the sequential

*Correspondence: preti@usp.br

${ }^{1}$ Division of Ophthalmology, University of São Paulo Medical School, São Paulo, SP, Brazil

Full list of author information is available at the end of the article tracked OCT findings of this outcome and discuss the mechanism of closure which may relate to Muller cell activation preceded by posterior vitreous detachment (PVD).

\section{Case report}

A 54-year-old female type 2 diabetic patient presented with a history of progressive vision loss of the left eye (OS). The right eye was legally blind due to end stage proliferative diabetic retinopathy (PDR).

On examination, best corrected visual acuity (VA) was hand motions in the right eye and 20/200 in the left eye. Ophthalmoscopic retinal examination OD was not possible due to a prepupillary fibrotic membrane. Retinal examination OS showed panretinal photocoagulation scars and evidence of regressed fibrotic PDR.

Spectral domain - optical coherence tomography (SD-OCT) OS illustrated a lamellar macular hole with epiretinal proliferation associated with cystic original author(s) and the source, provide a link to the Creative Commons licence, and indicate if changes were made. The images or other third party material in this article are included in the article's Creative Commons licence, unless indicated otherwise in a credit line to the material. If material is not included in the article's Creative Commons licence and your intended use is not permitted by statutory regulation or exceeds the permitted use, you will need to obtain permission directly from the copyright holder. To view a copy of this licence, visit http://creativecommons.org/licenses/by/4.0/. The Creative Commons Public Domain Dedication waiver (http://creativeco mmons.org/publicdomain/zero/1.0/) applies to the data made available in this article, unless otherwise stated in a credit line to the data. 

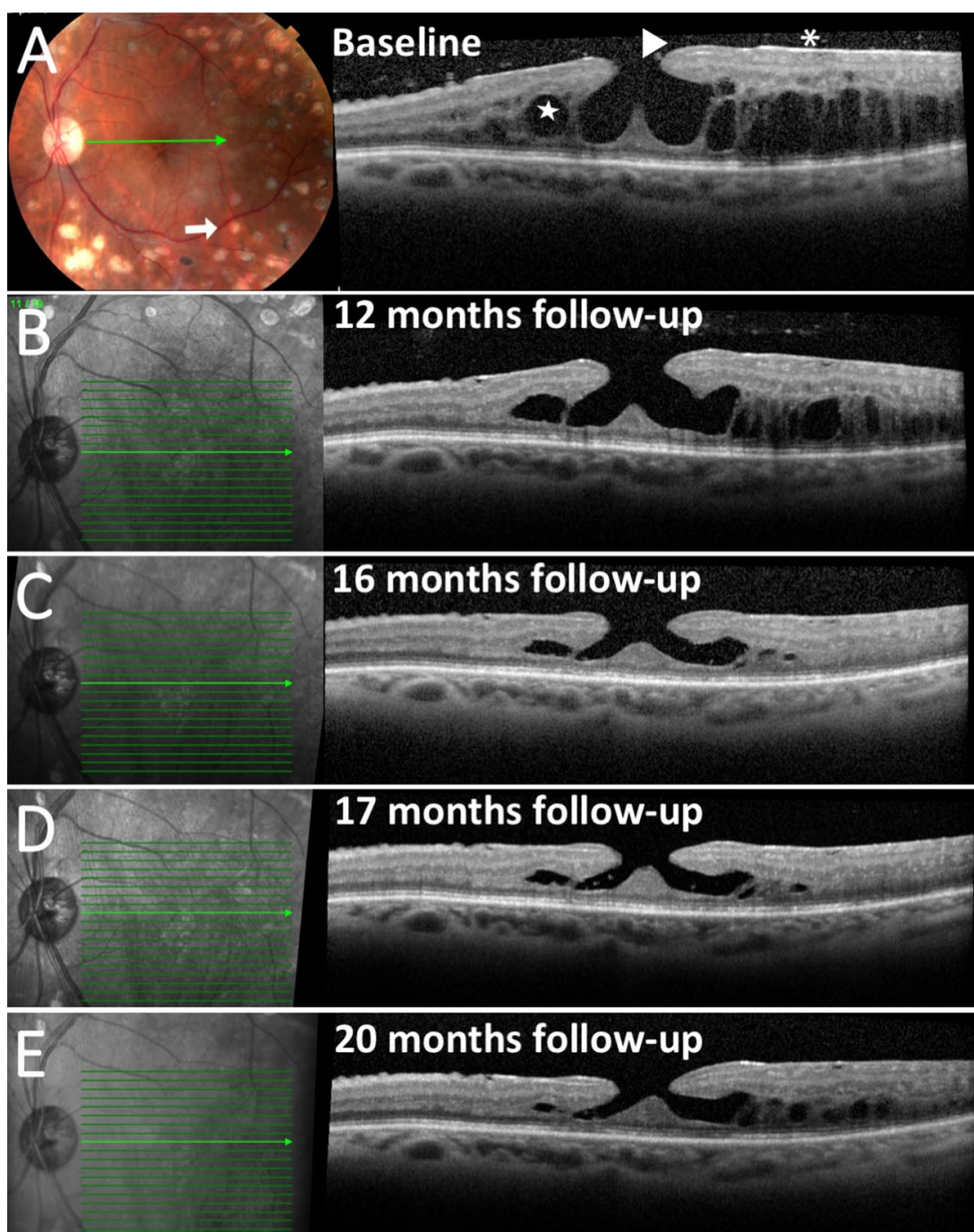

\section{0 months follow-up}
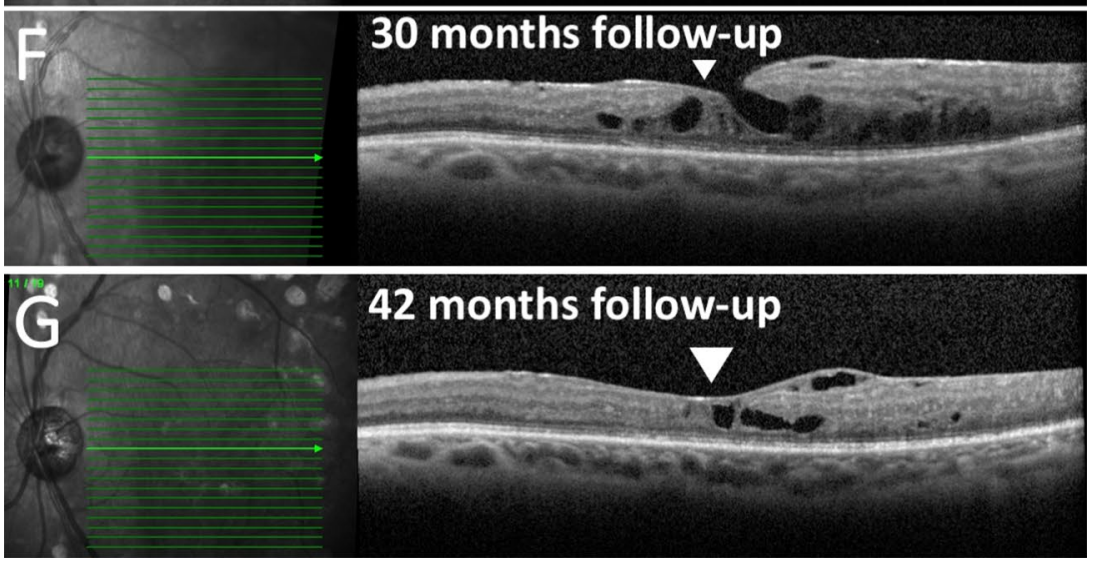

Fig. 1 A Left. Fundus photography shows multiple panretinal photocoagulation laser scars consistent with regressed proliferative diabetic retinopathy. Right, SD-OCT B-scan illustrates cysts in the outer nuclear layer (star), lamellar hole with epiretinal proliferation (LHEP) (arrow-heads), and epiretinal proliferation (asterisk). Note the grade 0 posterior vitreous detachment. B Left. Registered near infrared reflectance with level of OCT section Right. B-E A partial grade 3 PVD is noted. While LHEP is unchanged, CME is improved. E-G Progressive closure of the LMH (arrowheads) and resolution of the CME is illustrated with sequentially tracked SD-OCT B scans. Complete grade 4 PVD is noted 
degeneration predominantly located in the outer nuclear layer (Fig. 1A). A grade 0 PVD $[4,5]$ was also noted (Fig. 1A). The patient was treated with intravitreal bevacizumab injection (IVB) although the etiology of CME may have been related to traction associated with the ERM given the predominantly outer retinal location of the fluid.

SD-OCT 1 year later illustrated persistent LHEP, improvement of the CME and a partial grade 3 PVD (Fig. 1B). Sequentially tracked SD-OCT, obtained over the following 42 months, remarkably illustrated progressive closure of the LMH and near resolution of the CME associated with a complete PVD (Grade 4 PVD) (Fig. 1C-G). While the patient did receive 4 additional bevacizumab injections and focal macular laser, resolution of the CME may have been related to release of the PVD and closure of the lamellar macular hole. The final VA remained stable 20/200 OS.

\section{Discussion}

Degenerative epiretinal membranes (ERM) or lamellar macular holes (LMH) with epiretinal proliferation (LHEP) represent a distinct subset of ERM easily differentiated from tractional ERMs [6]. Although LHEP was first described as a result of complications of PVD, surgical and pathological studies have clearly demonstrated Muller cell proliferation associated with these lesions that may result from more degenerative related mechanisms [1]. LHEP has been associated with other degenerative disorders and not solely the result of PVD [7-9].

Muller cell activation and proliferation may lead to non-surgical closure of the LMH that was documented in this case report with sequentially tracked SD-OCT over 2 years [1]. Bringmann et al. described the spontaneous closure of a full thickness macular hole and indicated that Muller cell activation was the likely mechanism [8]. Others have described the spontaneous closure of LHEP but did not indicate if the sequential B scans were tracked [10]. In our case, complete PVD evolution may have also contributed to spontaneous closure of the LMH as a result of vitreoretinal traction release although these forms of LMH, i.e. LHEP, are not the result of tractional pathways.

Surgical management may be deferred in these cases due to the degenerative Muller cell component and the stable natural history.

\section{Conclusion}

LHEP may represent a specialized form of degenerative lamellar macular hole associated with Muller cell proliferation. Non surgical closure may rarely occur with these lesion types possibly due to Muller cell activation preceded by PVD.

\section{Acknowledgements}

Not applicable.

\section{Authors' contributions}

RCP and LCZ made substantial contributions to conceptualization, design, and the acquisition of data. LPC contributed by writing up the manuscript. MLRM and DS analyzed and interpreted the patient images, and helped in writing. All authors read and approved the final manuscript.

Funding

University of Sao Paulo provided their equipment for image acquisition.

\section{Availability of data and materials}

The data sets used and analyzed during the current study are available from the corresponding author on reasonable request.

\section{Declarations}

\section{Ethics approval and consent to participate}

Informed consent for publication of clinical details and/or images was obtained from the patient. Ethics approval is not applicable.

Consent for publication

Written informed consent was acquired.

\section{Disclosures}

David Sarraf: Amgen (consultant), Bayer (consultant), Genentech (consultant, research), Heidelberg (research), Novartis (speaker), Optovue (consultant, research), Regeneron (research), Topcon (research).

\section{Competing interests}

The following authors have no financial disclosures: RCP, LCZ, LPC, MRLM.

\section{Author details}

${ }^{1}$ Division of Ophthalmology, University of São Paulo Medical School, São Paulo, SP, Brazil. ${ }^{2}$ Department of Ophtalmology, School of Medicine, Federal University of Juiz de Fora, Juiz de Fora, Minas Gerais, Brazil. ${ }^{3}$ David Geffen School of Medicine at UCLA, Stein Eye Institute, Los Angeles, CA, USA. ${ }^{4}$ Greater Los Angeles Veterans Affairs Healthcare Center, Los Angeles, CA, USA.

Received: 29 July 2021 Accepted: 18 October 2021

Published online: 26 October 2021

\section{References}

1. Pang CE, Maberley DA, Freund KB, White VA, Rasmussen S, To E, et al. Lamellar hole-associated epiretinal proliferation: a clinicopathologic correlation. Retina. 2016;36(7):1408-12.

2. Choi WS, Merlau DJ, Chang S. Vitrectomy for macular disorders associated with lamellar macular hole epiretinal proliferation. Retina. 2018:38(4):664-9

3. Govetto A, Dacquay Y, Farajzadeh M, Platner E, Hirabayashi K, Hosseini H, et al. Lamellar macular hole: two distinct clinical entities? Am J Ophthalmol. 2016;164:99-109.

4. Ghadiali Q, Zahid S, Dolz-Marco R, Tan A, Engelbert M. An Assessment of vitreous degeneration in eyes with vitreomacular traction and macular holes. J Ophthalmol. 2017;2017:6834692.

5. Uchino E, Uemura A, Ohba N. Initial stages of posterior vitreous detachment in healthy eyes of older persons evaluated by optical coherence tomography. Arch Ophthalmol. 2001;119(10):1475-9.

6. Pang CE, Spaide RF, Freund KB. Epiretinal proliferation seen in association with lamellar macular holes: a distinct clinical entity. Retina. 2014;34(8):1513-23.

7. Siedlecki J, Vounotrypidis E, Vogt D, Wolf A, Priglinger SG, Schumann RG. Lamellar hole-associated epiretinal proliferation presenting with perifoveal exudative vascular anomalous complex. Am J Ophthalmol Case Rep. 2019;14:112-6. 
8. Semoun O, Miere A, Srour M, El Ameen A, Sikorav A, Querques G, et al. Lamellar hole associated with prominent intraretinal vessels. Retina. 2016;36(6):e43-4.

9. Itoh Y, Levison AL, Kaiser PK, Srivastava SK, Singh RP, Ehlers JP. Prevalence and characteristics of hyporeflective preretinal tissue in vitreomacular interface disorders. Br J Ophthalmol. 2016;100(3):399-404.

10. Bringmann A, Duncker T, Jochmann C, Barth T, Duncker GIW, Wiedemann P. Spontaneous closure of small full-thickness macular holes: Presumed role of Muller cells. Acta Ophthalmol. 2019;98:e447-56.

\section{Publisher's Note}

Springer Nature remains neutral with regard to jurisdictional claims in published maps and institutional affiliations.
Ready to submit your research? Choose BMC and benefit from:

- fast, convenient online submission

- thorough peer review by experienced researchers in your field

- rapid publication on acceptance

- support for research data, including large and complex data types

- gold Open Access which fosters wider collaboration and increased citations

- maximum visibility for your research: over $100 \mathrm{M}$ website views per year

At BMC, research is always in progress.

Learn more biomedcentral.com/submissions 